\title{
Retinoblastoma pT4a TNM Finding v7
}

National Cancer Institute

\section{Source}

National Cancer Institute. Retinoblastoma pT 4a TNM Finding v7. NCI Thesaurus. Code C88737.

Retinoblastoma with tumor invading optic nerve to resection line but no extra-ocular extension is identified. (from AJCC 7th Ed.) 